\title{
Acid Blue 80 Removal from Aqueous Solution by Activated Carbon Obtained from Nerium Oleander Fruits
}

\author{
Osman Üner \\ Kırklareli University, Faculty of Science and Art, Departmant of Chemistry, Kirklareli, Turkey \\ osmanuner@klu.edu.triD \\ Received date: 02.04.2021, Accepted date: 13.05.2021
}

\begin{abstract}
The present work reports acid blue 80 (AB80) adsorption performances on the activated carbon prepared from Nerium oleander fruits (NAC). Langmuir isotherm model and pseudo second order model were determined to be best fitting models for AB80 adsorption on NAC, and its maximum adsorption capacities were calculated to be 88.03, 102.04, and $113.96 \mathrm{mg} \mathrm{g}^{-1}$ at 25,35 , and $45^{\circ} \mathrm{C}$, respectively. Also, the efficiency of adsorption increased as adsorption $\mathrm{pH}$ decreased. While the adsorption rate was found to be fast during the first 60 minutes, adsorption velocity decreased with passing contact time. Moreover, via the thermodynamic parameters, the adsorption was determined to be spontaneous, feasible, and endothermic. From the FTIR spectra, the interactions of carbonyl groups on NAC with AB80 molecules and $\pi-\pi$ stacking interactions between NAC and AB80 molecules were determined to be possible interactions during the adsorption.
\end{abstract}

Keywords: Acid blue 80, textile dye, Nerium oleander fruits, adsorption, activated carbon

\section{Nerium Oleander Meyvelerinden Elde Edilen Aktif Karbon ile Sulu Çözeltiden Asit Mavi 80'in Giderimi}

$\ddot{\mathbf{O}} \mathbf{z}$

Bu çalışma, Nerium oleander meyvelerinden (NAC) hazırlanan aktif karbon üzerinde asit mavi 80 (AB80)'in adsorpsiyon performanslarını bildirmektedir. Langmuir izoterm modeli ve pseudo ikinci derece modeli, NAC üzerindeki AB80'in adsorpsiyonu için en uygun modeller olduğu belirlendi ve maksimum adsorpsiyon kapasiteleri 25 , 35 ve $45^{\circ} \mathrm{C}^{\prime}$ larda sirasıyla 88,03, 102,04 ve 113,96 mg g-1 olarak hesaplanmıştır. Ayrıca, adsorpsiyon pH'ı düştükçe, adsorpsiyon kapasitesi artmıştır. İlk 60 dakikada, adsorpsiyon hızı hızlı olduğu bulunurken, temas süresi geçtikçe adsorpsiyon hızı azaldı. Bununla beraber, termodinamik parametreler aracılığıyla, adsorpsiyonun kendiliğinden, uygulanabilir ve endotermik olduğu belirlendi. FTIR spektrumlarından, NAC üzerindeki karbonil gruplarının AB80 molekülleri ile etkileşimleri ve NAC ve AB80 molekülleri arasındaki $\pi$ - $\pi$ istifleme etkileşimleri adsorpsiyon esnasındaki olası etkileşimler olduğu belirlendi.

Anahtar Kelimeler: Asit mavi 80, tekstil boyas1, Nerium oleander meyveleri, adsorpsiyon, aktif karbon

\section{INTRODUCTION}

Each year, approximately 800,000 tons of dyes with higher than 1 million types whose half is textile dyes are produced worldwide (Hassaan and El Nemr, 2017; Ambati and Gogate, 2017). Synthetic dyes are significant materials used for the colorization or protection of any object. However, synthetic dyes have complex aromatic structures leading to them resist to spontaneous degradation in nature, and their contaminations in water may pose great threats for the environment and its inhabitants (Ali, 2010). In recent years, water contaminations due to dye stuff have come out as a growing issue (Hassaan and El Nemr, 2017).

Acid blue 80 is an anionic anthraquinone dye extensively utilized in textiles (e.g., fabrics, wools, silks, leather, nylons, and polyamide fibers), pesticides, cosmetics, sanitation, sterilants, disinfectants, detergents, and preservative applications (Ambati and Gogate, 2017; PuentesCárdenas et al., 2016). AB80 is mutagenic, carcinogenic, toxic, and resistant to degradation (Ambati and Gogate, 2017). Due to its potential for 
toxicity, bioaccumulation, and environmental persistence, Canadian Ministers of the Environment and Health has recognized $\mathrm{AB} 80$ as a priority substance (Puentes-Cárdenas et al., 2016). Also, in another study, by Tee and coworkers, AB80 was found to have a potential to be toxic at high concentrations (Tee et al., 2011).

Several techniques, such as adsorption (Sabarinathan et al., 2019; Tong et al., 2018; Üner et al., 2017; Üner et al., 2016), membrane filtration (Qiu et al., 2015), chemical oxidation (Türgay et al., 2011), and coagulation (Shankar et al., 2019; Shi et al., 2007), have been used for the treatments of dyecontaminated effluents. Among these techniques, adsorption has some superiority in terms of costeffectiveness and simplicity in its applications, and it is extensively utilized in industry (Rashid et al., 2021; Lakherwal, 2014). At adsorption applications to treat dye-contaminated wastewaters, activated carbons are one of the most usually preferred adsorbents because activated carbons have immense surface areas, high degrees of surface reactivity, high mechanical strength, good adsorptive capacities, high stabilities, and high porosities (Yahya et al., 2015; Ince and Kaplan, 2017). However, in spite of its efficient uses in adsorption processes, activated carbons have big barriers in their industrial applications, such as high costs and the difficulties related to regeneration (Bak1c1 et al., 2020; Wong et al., 2018; Rashidi and Yusup, 2017). Therefore, in recent years, waste materials, such as Mangosteen peel waste (Nasrullah et al., 2019), Lemon Peel (Bhattacharyya et al., 2019), sunflower piths (Baysal et al., 2018), denim fabric waste (Silva et al., 2018), okra wastes (Üner et al., 2017), potato peels (Kyzas et al., 2016), grape bagasse (Demiral and Güngör, 2016), watermelon rind (Üner et al., 2019), have widely been used as precursors to produce low-cost activated carbons.

Nerium oleander plants in western Turkey have fruits starting to fall down on the ground usually in September. These fruits do not have any usage area in close-areas where these plants are, and also they are not edible, so these fruits begin to decay on the ground after a certain period of time. Therefore, activated carbon (NAC) was produced from Nerium oleander plants and they were optimized in the previously published paper (Üner et al., 2021). However, its adsorption performances have not been researched for synthetic dyes. The objective of this study is to evaluate Acid Blue 80 adsorption performance of NAC. For this aim, adsorption data obtained by varying some parameters, such as contact time, adsorbent dosage, initial AB80 concentration, adsorption temperature, and $\mathrm{pH}$ were analyzed. Furthermore, isotherm model, kinetic, and thermodynamic studies were carried out.

\section{MATERIAL AND METHODS Materials}

Nerium oleander fruits in dry form were obtained from Sirince village, $12 \mathrm{~km}$ away from Ephesus, İzmir in Turkey. Potassium nitrate and zinc chloride were supplied from Merck. Acid blue 80 (CAS: 4474-24-2, dye content 40\%) with molecular formula of $\mathrm{C}_{32} \mathrm{H}_{28} \mathrm{~N}_{2} \mathrm{Na}_{2} \mathrm{O}_{8} \mathrm{~S}_{2}$ and molecular weight of $678.68 \mathrm{~g} \mathrm{~mol}^{-1}$, hydrogen chloride (38 wt\%), and sodium hydroxide were obtained by Sigma-Aldrich.

\section{Batch Adsorption Studies}

Batch sorption experiments (Hameed and Ahmad, 2009) were studied to find out the effects of experimental conditions on AB80 adsorption by NAC. Experimental conditions were adjusted in accordance with the parameter to be studied for AB80 adsorption on NAC in range of $0.1-3.2 \mathrm{mg}$ $\mathrm{mL}^{-1}$ for adsorbent dosage, $40-160 \mathrm{mg} \mathrm{L}^{-1}$ for initial AB80 concentration, $25-45{ }^{\circ} \mathrm{C}$ for adsorption temperature, and 0-1320 minutes for contact time, and 2.06-10.41 for $\mathrm{pH}$ (inoLab, $\mathrm{pH}$ 7310). For AB80 adsorption experiments, AB80 stock solution of $1000 \mathrm{mg} \mathrm{L}^{-1}$ was prepared by solving $1 \mathrm{~g} \mathrm{AB} 80$ with $1000 \mathrm{~mL}$ double-distilled water, and then $\mathrm{AB} 80$ solutions with desired concentrations were adjusted to $40,80,120$, and $160 \mathrm{mg} \mathrm{L}^{-1}$ by diluting the $\mathrm{AB} 80$ stock solution. AB80 solutions with $50 \mathrm{~mL}$ at adjusted concentrations were transferred into 100 $\mathrm{mL}$ Erlenmeyer flasks in which various amounts of NACs. These Erlenmeyer flasks were put into a thermostat controlled shaker (Lab. Companion, BS- 
21) to be shaken at $125 \mathrm{rpm}$ for 1320 minutes till reaching adsorption equilibriums. After that, NAC was waited to sink to the bottom for 30 minutes, and supernatants were taken off with Pasteur pipettes. The supernatants were centrifuged at $5000 \mathrm{rpm}$ for 20 minutes (Universal 320, Hettich Zentrifugen), and then the absorbance values of liquid phases were measured by means of a UV-Vis spectrophotometer (Shimadzu, UV-2600) at the wavelength of $626 \mathrm{~nm}$.

The removal percentages of AB 80 by NAC were calculated according to the following formula:

Removal $(\%)=\frac{\left(C_{i}-C_{e}\right)}{C_{i}} \times 100$

Also, the equation below was used to calculate $\mathrm{q}_{\mathrm{e}}$ value which is adsorbed AB80 amount by per unit mass of NAC.

$q_{e}=\frac{\left(C_{i}-C_{e}\right) \mathrm{V}}{w}$

where $\mathrm{C}_{\mathrm{i}}, \mathrm{C}_{\mathrm{e}}, \mathrm{V}$, and $w$ represent initial $\mathrm{AB} 80$ concentration $\left(\mathrm{mg} \quad \mathrm{L}^{-1}\right), \quad \mathrm{AB} 80$ equilibrium concentration $\left(\mathrm{mg} \mathrm{L}^{-1}\right)$, solution volume $(\mathrm{L})$, and NAC mass (g), respectively.

To study the effect of initial $\mathrm{pH}$, initial $\mathrm{pH}$ values of $\mathrm{AB} 80$ solutions $\left(80 \mathrm{mg} \mathrm{L}^{-1}\right)$ were adjusted to the values between 2.06 and 10.41 adding the diluted solution of $\mathrm{HCl}$ or $\mathrm{NaOH}(0.1 \mathrm{~mol} \mathrm{~L}-1)$ drop by drop. Then, NAC $\left(0.4 \mathrm{mg} \mathrm{mL}^{-1}\right)$ is added to these $\mathrm{pH}$ adjusted solution, and it was shaken in a thermostat controlled shaker at $125 \mathrm{rpm}$ for more than 1320 minutes till reaching adsorption equilibriums. To calculate the removal percentages of $\mathrm{AB} 80$ solutions by NAC, the same procedure above was carried out.

The point of zero charge of NAC was determined by using batch equilibrium procedure (Milonjić et al., 1975). The point of zero charge measurement was carried out as follows: the $\mathrm{pH}$ values $50 \mathrm{~mL} 0.1 \mathrm{M} \mathrm{KNO}_{3}$ solutions in Erlenmeyer flasks were adjusted between 2.3 and 11.4 with 0.1 $\mathrm{HCl}$ or $\mathrm{NaOH}$ additions by using a $\mathrm{pH}$ meter (inoLab $\mathrm{pH}$ 7310). After that, $0.1 \mathrm{~g}$ NAC was added into each Erlenmeyer flask, and they were agitated at $125 \mathrm{rpm}$ for 2 days. After ultimate $\mathrm{pH}$ values were measured, they were plotted versus initial pHs.

\section{Adsorption Equilibrium}

Langmuir isotherm model (Langmuir, 1916) was applied for AB80 adsorption on NAC by using the following formula.

$q_{e}=\frac{q_{\max } K_{L} C_{e}}{1+K_{L}}$

where $q_{\max }$ and $K_{L}$ represent the maximum adsorption capacity $\left(\mathrm{mg} \mathrm{g}^{-1}\right)$ and Langmuir constant $\left(\mathrm{L} \mathrm{mg}^{-1}\right)$, respectively.

Freundlich isotherm model (Freundlich, 1906) was applied by using the following formula.

$q_{e}=K_{F} C_{e}^{n^{-1}}$

where $K_{F}$ and $l n^{-1}$ stand for Freundlich constant $\left(\mathrm{mg} \quad \mathrm{g}^{-1} \quad\left(\mathrm{~L} \quad \mathrm{mg}^{-1}\right)^{1 / \mathrm{n}}\right)$ and surface heterogeneity or and the adsorption intensity.

Temkin isotherm model (Temkin and Pyzhev, 1940) was applied by using the following formula.

$q_{e}=\frac{R T}{B_{T}} \ln \left(A_{T} C_{e}\right)$

$B_{T}, A_{T}$, and $R$ symbolize Temkin isotherm constant $\left(\mathrm{J} \mathrm{mol}^{-1}\right)$, Temkin isotherm equilibrium binding constant $\left(\mathrm{L} \mathrm{g} \mathrm{g}^{-1}\right)$, and universal gas constant $\left(8.314 \mathrm{~J}(\mathrm{~mol} \mathrm{~K})^{-1}\right)$, respectively.

Dubinin-Radushkevich (D-R) isotherm model (Dubinin and Radushkevich, 1947) was applied by using the following formulas.

$\ln q_{e}=\ln q_{d}-\beta \varepsilon^{2}$

$\varepsilon=R T \ln \left[1+\frac{1}{C_{e}}\right]$

$E=\frac{1}{\sqrt{2 \beta}}$

$q_{d}, \beta, \varepsilon$, and $E$ stand for D-R constant $\left(\mathrm{mg} \mathrm{g}^{-1}\right)$, the constant related to free energy, Polanyi potential, and the mean free energy $\left(\mathrm{kJ} \mathrm{mol}^{-1}\right)$, respectively. 


\section{Kinetic Studies}

Pseudo first order kinetic model (Lagergren, 1898) was applied for AB80 adsorption on NAC by using the following formula.

$\log \left(q_{e}-q_{t}\right)=\log q_{e}-\frac{k_{1}}{2.303} t$

where $q_{e}, q_{t}$, and $k_{l}$ represent the adsorption capacity at equilibrium (mg g $\left.\mathrm{g}^{-1}\right)$, the adsorption capacity $\left(\mathrm{mg} \mathrm{g}^{-1}\right)$ at time $\mathrm{t}(\mathrm{min})$, and the pseudo first-order rate constant $\left(\mathrm{min}^{-1}\right)$, respectively.

Pseudo second order kinetic model (Ho and McKay, 1999) was applied for AB80 adsorption on NAC by using the following formula.

$\frac{t}{q_{t}}=\frac{1}{k_{2} q_{e}^{2}}+\frac{1}{q_{e}} t$

where $q_{e}, q_{t}$, and $k_{2}$ represent the adsorption capacity at equilibrium $\left(\mathrm{mg} \mathrm{g}^{-1}\right)$, the adsorption capacity $\left(\mathrm{mg} \mathrm{g}^{-1}\right)$ at time $\mathrm{t}(\mathrm{min})$, and the pseudo

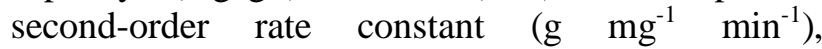
respectively.

\section{Thermodynamic Studies}

Gibbs free energy $\left(\Delta G^{\circ}\right)$, enthalpy $\left(\Delta H^{\circ}\right)$, and entropy $\left(\Delta S^{\circ}\right)$ were calculated with the following formulas (Pandiarajan et al. 2018).

$$
\Delta G^{\circ}=-R T \ln K_{c}
$$

$K_{c}=\frac{C_{s}}{C_{e}}$

$\ln K_{C}=\frac{\Delta \mathrm{S}^{\circ}}{R}-\frac{\Delta \mathrm{H}^{\circ}}{R T}$

where $K_{c}, C_{s}, C_{e}, T$, and $R$ stand for equilibrium constant, solid phase concentration of $\mathrm{AB} 80$ at equilibrium $\left(\mathrm{mg} \mathrm{L}^{-1}\right)$, equilibrium concentration in solution $\left(\mathrm{mg} \mathrm{L}^{-1}\right)$, absolute temperature $(\mathrm{K})$, and the universal gas constant $\left(8.314 \mathrm{~kJ} \mathrm{~mol}^{-1}\right)$, respectively.

\section{RESULTS AND DISCUSSION Calibration Curve}

Uv-vis absorption curves of AB80 between 200 and $800 \mathrm{~nm}$ were obtained to determine working concentrations and wavelength before adsorption experiments. The calibration curve of $\mathrm{AB} 80$ with the concentrations in range of $0.4-8 \mathrm{mg} \mathrm{L}^{-1}$ at wavelength of $626 \mathrm{~nm}$ was drawn. Its $\mathrm{R}^{2}$ value was calculated to be 0.9999 , and its equation was obtained as $\mathrm{y}=0.06312 \mathrm{x}-8.90057 \mathrm{e}^{-4}$.

\section{Effect of Contact Time}

To determine the adsorption time which is sufficient for reaching AB80 adsorption equilibrium on NAC, the effect of contact time was investigated. The effect of contact time on AB80 adsorption at various initial $\mathrm{AB} 80$ concentrations ranging from 40 to $160 \mathrm{mg} \mathrm{L}^{-1}$ on NAC is shown in Figure 1. As contact time passed, the removal percentage of AB80 from the solution by NAC increased for all studied $\mathrm{AB} 80$ concentrations till reaching adsorption equilibrium. From Figure 1, the rates of AB80 adsorptions at all initial AB80 concentrations are fast during the first 60 minutes because first the positively charged active sites of NACs are easily accessible by negatively charged $\mathrm{AB} 80$ molecules. However, as easily accessible vacant sites are filled with negatively charged AB80 molecules, access to active sites becomes more difficult than before, hence the rate of $\mathrm{AB} 80$ adsorption slows down. AB80 adsorption on NAC reached adsorption equilibrium at $840,960,1080$, and 1200 minutes for the initial AB80 concentrations of 40,80, 120, and $160 \mathrm{mg} \mathrm{L} \mathrm{L}^{-1}$, respectively. Therefore, all studied AB80 adsorption experiments except kinetic experiments were carried out with the contact time of 1320 minutes. 


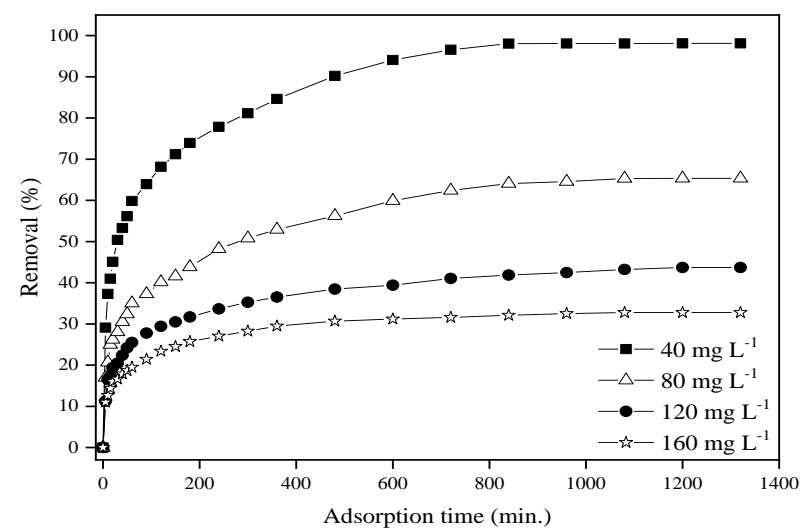

Figure 1. Effect of contact time on $\mathrm{AB} 80$ removal at various initial dye concentrations (Conditions: adsorbent dosage $=$ $0.6 \mathrm{mg} \mathrm{mL}^{-1}$, temperature $=25^{\circ} \mathrm{C}$, dye solution $\mathrm{pH}=$ original, and agitation speed $=125 \mathrm{rpm}$ )

\section{Effect of Adsorbent Dosage}

Figure 2(a-c) displays NAC dose effect on the removal percentage of $\mathrm{AB} 80$ with the different concentration of $40,80,120$, and $160 \mathrm{mg} \mathrm{L}^{-1}$ at three different temperatures of 25,35 , and $45^{\circ} \mathrm{C}$. Also, experimental results showed in Figure 2(d) that the colors of AB80 solutions opens from left to right as the amount of activated carbon increases. As the NAC dosage increases for each $\mathrm{AB} 80$ concentration studied, AB80 removal percentage increases until there is no molecule in solution. As shown in Figure 2(a), 0.68, 1.33, 1.95, and $2.60 \mathrm{mg} \mathrm{mL}^{-1} \mathrm{NAC}$ are sufficient for the removals of $40,80,120$, and $160 \mathrm{mg} \mathrm{L}^{-1} \mathrm{AB} 80$ at $25^{\circ} \mathrm{C}$, respectively, in order to remove $\mathrm{AB} 80$ with the percentage of higher than 99.00\% from the aqueous solution. Also, 0.65, 1.30, 1.85 , and $2.40 \mathrm{mg} \mathrm{mL}^{-1} \mathrm{NAC}$ at the adsorption temperature of $35^{\circ} \mathrm{C}$ and $0.60,1.10,1.65$, and 2.02 $\mathrm{mg} \mathrm{mL}^{-1} \mathrm{NAC}$ at the adsorption temperature of 45 ${ }^{\circ} \mathrm{C}$ are adequate for the higher than $99.00 \%$ removals of $40,80,120$, and $160 \mathrm{mg} \mathrm{L}^{-1} \mathrm{AB} 80$, respectively, as seen in Figure $2(b-c)$. When using higher than sufficient NAC amount, AB80 adsorption on NAC ends when any $\mathrm{AB} 80$ molecule does not remain in solution. Therefore, excessive use of NAC is unnecessary in terms of cost-effect.

\section{Effect of Initial AB80 Concentration}

If the parameters affecting the adsorption capacity are kept constant in solution, and if only initial AB80 concentration is increased, $\mathrm{AB} 80$ removal percentage from the solution will decrease as expected. For instance, AB80 removal percentages were determined to be $93.43,55.91$, 36.40 , and 26.6 when NAC amount was used as 0.5 $\mathrm{mg} \mathrm{mL}{ }^{-1}$ at adsorption temperature of $25{ }^{\circ} \mathrm{C}$ in Figure 2(a). On the other hand, AB80 removal percentages were higher than $99.00 \%$ when NAC amount was used higher than $2.60 \mathrm{mg} \mathrm{mL}^{-1}$ for all AB80 concentrations studied. This is because, 2.60 $\mathrm{mg} \mathrm{mL}^{-1} \mathrm{NAC}$ is sufficient for the removal of AB80 with $160 \mathrm{mg} \mathrm{L}^{-1}$, but $2.60 \mathrm{mg} \mathrm{mL}^{-1} \mathrm{NAC}$ is excessive for 40,80 , and $120 \mathrm{mg} \mathrm{L}^{-1} \mathrm{AB} 80$ removals due to the lack of $\mathrm{AB} 80$ molecules in solution. Similar trend is observed for AB80 adsorptions at 35 and $45{ }^{\circ} \mathrm{C}$, as seen in Figure 2(bc). The significant point is to use optimum NAC amount which is proper to $\mathrm{AB} 80$ concentration. This will decrease the costs. 

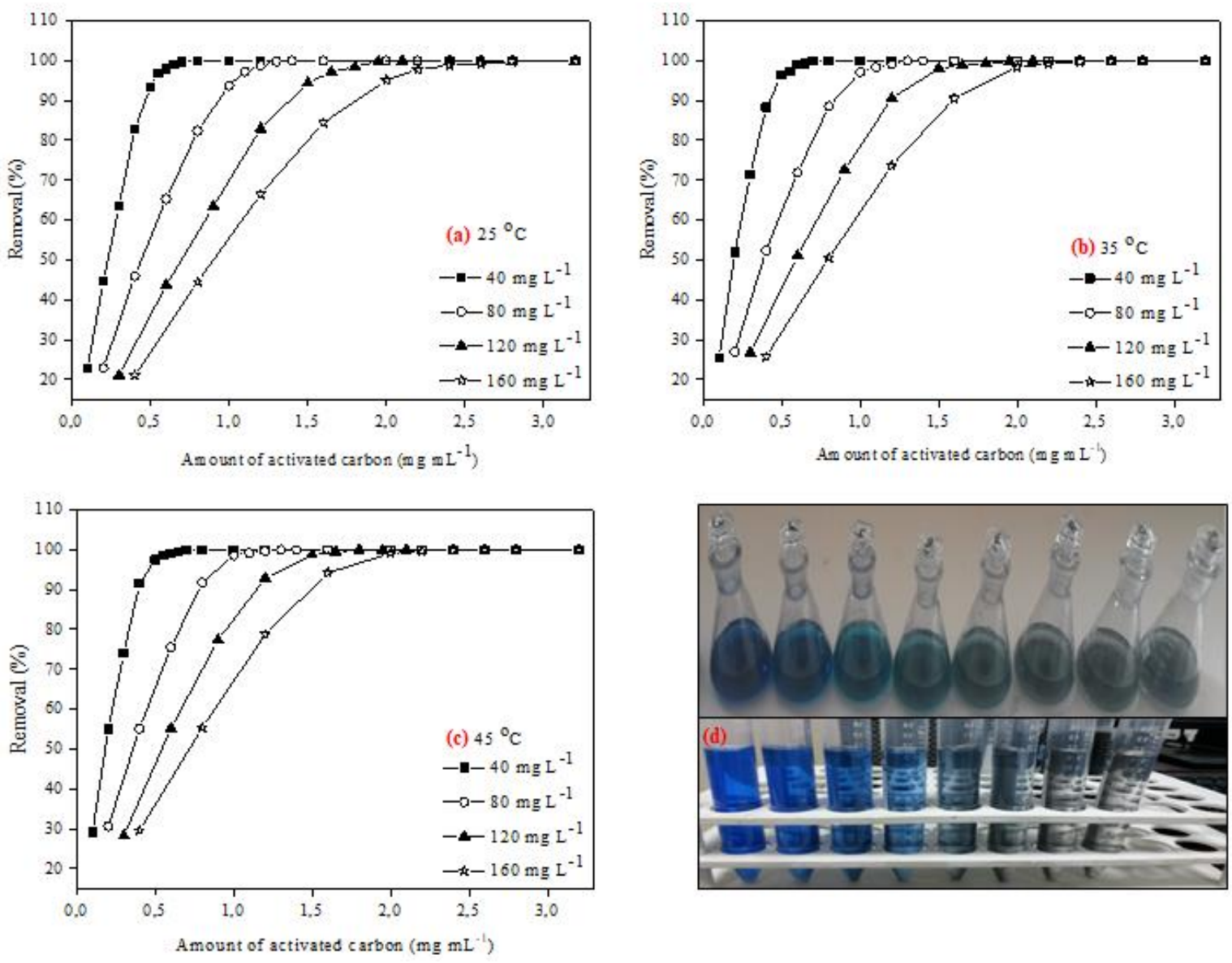

Figure 2. The adsorbent dose versus the removal percentage of AB80 with the different concentration of 40, 80, 120 , and $160 \mathrm{mg} \mathrm{L}^{-1}$ at three different temperatures of (a) 25 , (b) 35 , and (c) $45^{\circ} \mathrm{C}$, and also (d) experimental results of their colours; opening colours from left to right as the amount of activated carbon increases (Conditions: agitation speed $=125 \mathrm{rpm}$ and dye solution $\mathrm{pH}=$ original)

\section{Effect of Adsorption Temperature}

Figure $3(\mathrm{a}-\mathrm{d})$ proves that increasing adsorption temperature led to increase in $\mathrm{AB} 80$ adsorption capacity by NAC. This can be explained that chemical interactions between $\mathrm{AB} 80$ ions and surface groups on NAC largely affect $\mathrm{AB} 80$ adsorption capacity by NAC. Similar results were obtained by other studies (Aboua et al., 2015; Karim et al., 2006). Increasing AB80 adsorption with adsorption temperature might be because of the chemical interactions between $\mathrm{AB} 80$ ions and surface groups or because of the increase in the rate of the AB80 ion intraparticle diffusion into pores at elevated adsorption temperatures (Aboua et al., 2015). 

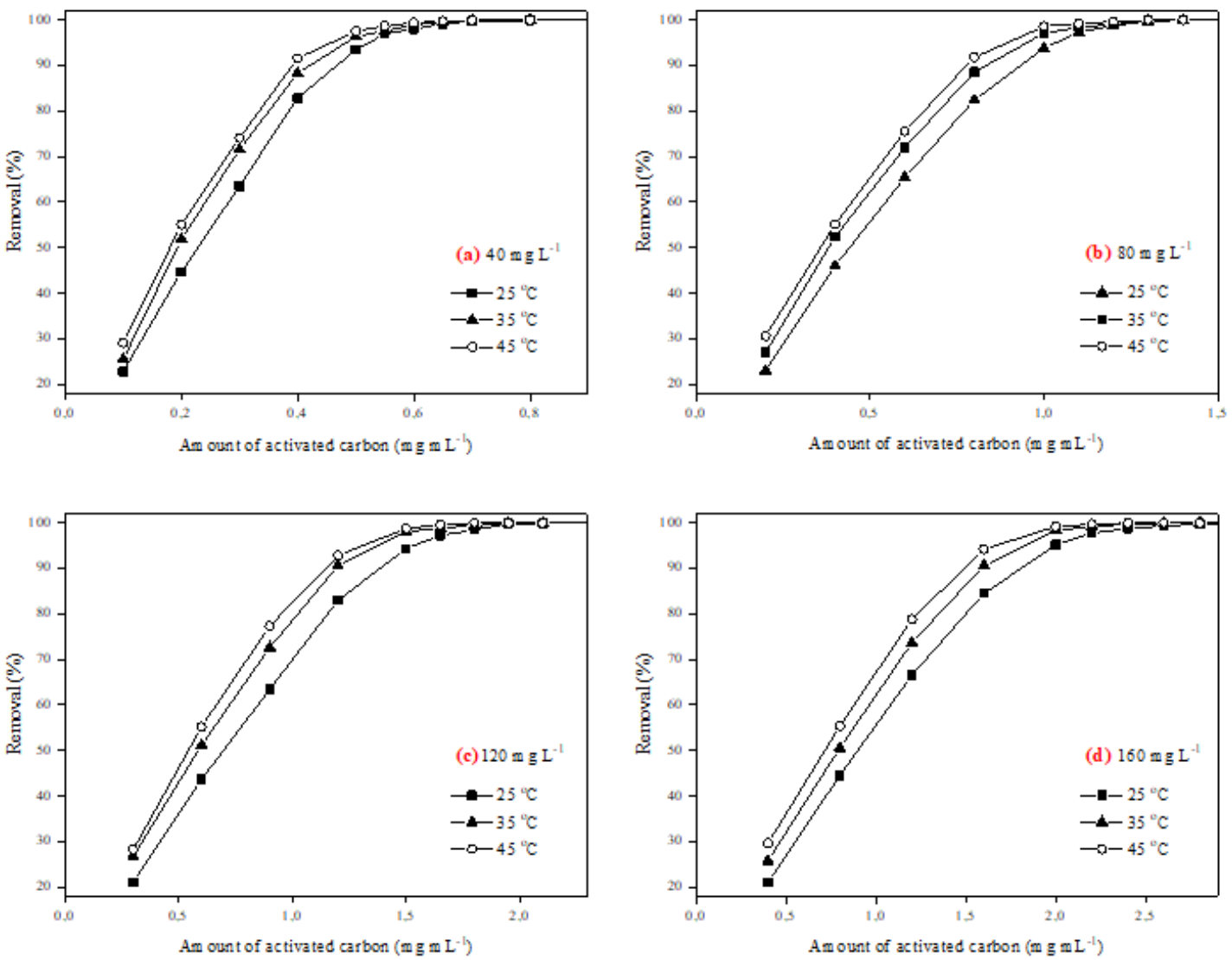

Figure 3. Temperature effect on the adsorption of AB80 with the different concentration of (a) 40, (b) 80, (c) 120, and (d) $160 \mathrm{mg} \mathrm{L}^{-1}$ (Conditions: agitation speed $=125 \mathrm{rpm}$ and dye solution $\mathrm{pH}=$ original)

\section{Effect of Initial pH}

The point of zero charge was determined to be 6.87, as seen in Figure 4(a). The surface of NAC is positively charged at pHs below values of 6.87 , while it is negatively charged at $\mathrm{pHs}$ higher than 6.87. As shown in Figure 4(b), AB80 adsorption capacity increases as adsorption $\mathrm{pH}$ decreases. This may be clarified with PZC of NAC that AB80 is negatively charged ion in solution, and the surface of NAC is more positively charged as pHs decreases from 6.87 to below values. Thus, as adsorption $\mathrm{pH}$ decreases, AB80 adsorption capacity increases due to the attractions between negatively charged AB80 ions and positively charged NAC surface. On the other hand, the surface of NAC is more negatively charged as pHs increases from 6.87 to higher values. As adsorption $\mathrm{pH}$ increases, AB80 adsorption capacity decreases due to the repulsions between negatively charged $\mathrm{AB} 80$ ions and negatively charged NAC surface. 

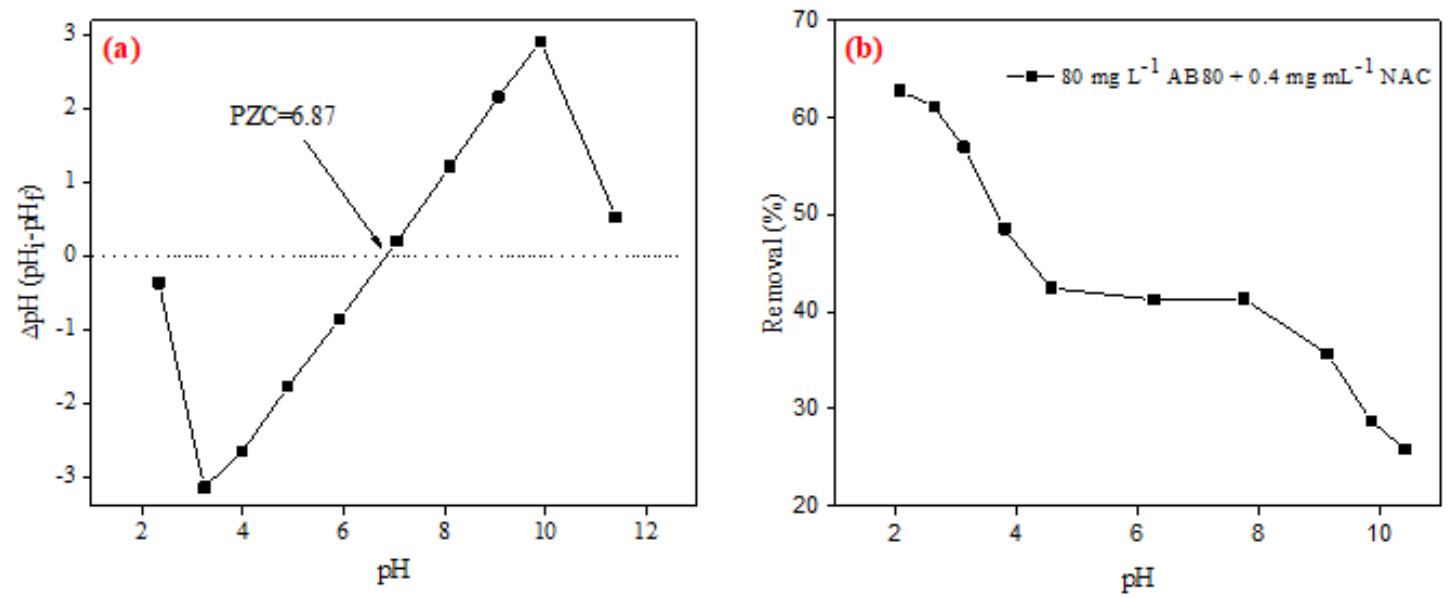

Figure 4. (a) Determination of point of zero charge (PZC) of NAC and (b) initial pH the effect on AB80 adsorption onto NAC (Conditions: temperature $=25^{\circ} \mathrm{C}$ and agitation speed $=125 \mathrm{rpm}$ )

\section{Adsorption Kinetics}

The rate constants of Lagergren pseudo first order and pseudo second order models were calculated by utilizing intercepts and slopes of these model fits, and kinetic parameters for $\mathrm{AB} 80$ adsorption onto NAC at $25{ }^{\circ} \mathrm{C}$ were recorded in Table 1. From the results in Table $1, \mathrm{R}^{2}$ values (0.993-0.998) obtained for pseudo second order model were determined to be higher than those obtained for pseudo first order model (0.833-0.927), which means that pseudo second order model is the best fitting model to the experimental data of AB80 adsorption on NAC. Also, the maximum AB80 adsorption capacities calculated by using pseudo second order model were found to be close to experimental adsorption capacities. Pseudo second order model shows that chemisorption process can control AB80 adsorption on NAC by occurring electron sharing between AB80 molecules and the surface groups of NAC (Ho and McKay 1999).

\section{Adsorption Isotherm}

Langmuir, Freundlich, Temkin, and DubininRadushkevich adsorption isotherm models were utilized to describe NAC-AB80 interaction and AB80 molecule distribution at solid-liquid phases. The calculated parameters of these isotherm models for AB80 adsorption onto NAC are given in Table 2. The Langmuir isotherm model has higher $\mathrm{R}^{2}$ values (1.000-0.999) compared to the others, which indicates that Langmuir model better describes AB80 adsorption process on NAC than the others. Langmuir isotherm model suggests that $\mathrm{AB} 80$ adsorption on NAC is monolayer with homogeneous sites (Martins et al., 2015). Also, NAC for AB80 adsorption displayed quite good maximum adsorption capacities which were calculated to be $88.03,102.04$, and $113.96 \mathrm{mg} \mathrm{g}^{-1}$ at 25,35 , and 45 ${ }^{\circ} \mathrm{C}$, respectively.

There are some maximum adsorption capacities $\left(\mathrm{q}_{\max }\right)$ for $\mathrm{AB} 80$ on various adsorbents at between 20 and $30{ }^{\circ} \mathrm{C}$ in literature. For instance, the maximum adsorption capacity of $\mathrm{AB} 80$ with surfactantmodified bentonite is $38.15 \mathrm{mg} \mathrm{g}^{-1}$ (Balarak et al., 2018 , and the maximum adsorption capacity of AB80 with Modified bentonite is $201.00 \mathrm{mg} \mathrm{g}^{-1}$ (Gomri et al., 2016). Another adsorbent used for $\mathrm{AB} 80$ is $\mathrm{Cu}-\mathrm{TiO}_{2}$, and its maximum adsorption capacity is $22.23 \pm 1.87 \mathrm{mg} \mathrm{g}^{-1}$ (Puentes-Cárdenas et al., 2016). While the maximum adsorption capacity of AB80 with potato residue based activated carbon is $156.22 \mathrm{mg} \mathrm{g}^{-1}$ (Liu et al., 2015), the maximum adsorption capacity of $\mathrm{AB} 80$ with mango seed is $9.20 \mathrm{mg} \mathrm{g}^{-1}$ (Dávila-Jiménez et al., 2009). Compared 
with examples of the maximum AB80 adsorption capacities in the literature, Nerium oleander fruits are a relatively feasible precursor of efficient activated carbon for $\mathrm{AB} 80$ adsorption.

\section{Thermodynamics}

As seen in Table 3, thermodynamic parameters which are $\Delta \mathrm{H}^{\circ}, \Delta \mathrm{S}^{\circ}$ and $\Delta \mathrm{G}^{\circ}$ for $\mathrm{AB} 80$ adsorption onto NAC were calculated by plotting $\ln \mathrm{K}_{\mathrm{c}}$ versus $1 / \mathrm{T}$ for temperatures ranging from 25 to $45^{\circ} \mathrm{C}$. All $\Delta \mathrm{G}^{\circ}$ values for $\mathrm{AB} 80$ adsorption on NAC have negative values at the adsorption temperature of 25 , 35 , and $45{ }^{\circ} \mathrm{C}$, indicating spontaneous and feasible process. $\Delta \mathrm{G}^{\circ}$ values decrease with the increase in adsorption temperature, which means that AB80 adsorption on NAC is more spontaneous at high temperatures. Furthermore, $\Delta \mathrm{H}^{\circ}$ value is positive, which shows that AB80 adsorption on NAC is endothermic. Also, $\Delta \mathrm{S}^{\circ}$ value for $\mathrm{AB} 80$ adsorption on NAC is positive, which indicates the increase in the degree of freedom of AB80 adsorption system (Aboua et al., 2015).

\section{FTIR Spectra}

To determine functional groups related to the interaction between NAC and $\mathrm{AB} 80$ molecule during the adsorption, FTIR spectra of NAC before and after AB80 adsorption were obtained by using FTIR spectroscopy (Thermo FT-IR), and they are given in Figure 5. The peaks at $2921-2852 \mathrm{~cm}^{-1}$ are attributed to symmetric and asymmetric stretching in methylene and methyl groups (Koçer and
Acemioğlu, 2016). The peak at $1722 \mathrm{~cm}^{-1}$ is attributed to carbonyl $(\mathrm{C}=\mathrm{O})$ stretching (Köseoğlu and Akmil-Başar, 2015). The band at $1574 \mathrm{~cm}^{-1}$ identifies the $\mathrm{C}=\mathrm{O}$ stretching (Ai et al., 2011). The bands between 1510 and 1425 $\mathrm{cm}^{-1}$ identify the skeletal $\mathrm{C}=\mathrm{C}$ vibrations in aromatic rings (Ma et al., 2016; Baccar et al., 2009). The peak at $1377 \mathrm{~cm}^{-1}$ identify the plane bending of $\mathrm{CH}$, skeletal CCC, and enolic $\mathrm{COH}$ (Mohan et al., 2012; Baccar et al., 2009). The bands between 1300 and $1000 \mathrm{~cm}^{-1}$ identify the $\mathrm{OH}$ bending and $\mathrm{C}-\mathrm{O}$ stretching vibrations of alcohols and carboxylic acids (Köseoğlu and Akmil-Başar, 2015; Abechi et al., 2013; Beltrame et. al., 2018). The peak at 1154 $\mathrm{cm}^{-1}$ is attributed to $\mathrm{C}-\mathrm{H}$ aromatic stretching in phenolics (Nogales-Bueno et al., 2017). The peaks between 900 and $700 \mathrm{~cm}^{-1}$ identifies the aromatic, out of plane $\mathrm{C}-\mathrm{H}$ bending (Köseoğlu and AkmilBaşar, 2015). In Figure 5, the shifting of the peak from 1577 to $1571 \mathrm{~cm}^{-1}$ after AB80 adsorption indicates that carbonyl groups involved in the interaction between NAC and AB80 during the adsorption. Also, the shifting of the peak from 1162 to $1153 \mathrm{~cm}^{-1}$ after $\mathrm{AB} 80$ adsorption suggests that aromatic groups in phenolics involved in the interaction between NAC and AB80 during the adsorption. Therefore, the interactions of carbonyl groups on NAC with $\mathrm{AB} 80$ molecules and $\pi$ - $\pi$ stacking interactions between NAC and AB80 molecules are possible interactions during the adsorption.

Table 1. Kinetic parameters for the adsorption of $A B 80$ onto $N A C$ at $25^{\circ} \mathrm{C}$

\begin{tabular}{|l|l|l|l|l|l|l|l|}
\hline \multirow{2}{*}{$\begin{array}{c}\mathrm{C}_{\mathrm{o}} \\
\left(\mathrm{mg} \mathrm{L}^{-1}\right)\end{array}$} & \multirow{2}{*}{$\begin{array}{c}\mathrm{q}_{\mathrm{e}, \text { exp }} \\
\left(\mathrm{mg} \mathrm{g}^{-1}\right)\end{array}$} & \multicolumn{3}{c|}{ Pseudo-first-order } & \multicolumn{3}{c|}{ Pseudo-second-order } \\
\cline { 3 - 8 } & & $\begin{array}{l}\mathrm{k}_{1} \\
\left(1 \mathrm{~min}^{-1}\right)\end{array}$ & $\begin{array}{l}\mathrm{q}_{\mathrm{e}, \mathrm{cal}} \\
\left(\mathrm{mg} \mathrm{g}^{-1}\right)\end{array}$ & $\mathrm{R}^{2}$ & $\begin{array}{l}\mathrm{k}_{2} \times 10^{-3} \\
\left(\mathrm{~g}(\mathrm{mg} \mathrm{min})^{-1}\right)\end{array}$ & $\begin{array}{l}\mathrm{q}_{\mathrm{e}, \mathrm{cal}} \\
\left(\mathrm{mg} \mathrm{g}^{-1}\right)\end{array}$ & $\mathrm{R}^{2}$ \\
\hline 40 & 65.41 & 0.0071 & 54.08 & 0.927 & 0.341 & 67.48 & 0.997 \\
\hline 80 & 87.12 & 0.0051 & 70.18 & 0.868 & 0.186 & 89.60 & 0.993 \\
\hline 120 & 87.42 & 0.0043 & 59.66 & 0.833 & 0.233 & 88.65 & 0.997 \\
\hline 160 & 87.38 & 0.0053 & 55.47 & 0.888 & 0.293 & 89.21 & 0.998 \\
\hline
\end{tabular}


Table 2. Adsorption isotherm parameters for AB80 adsorption on NAC

\begin{tabular}{|l|l|c|c|c|}
\hline Temperature $\left({ }^{\circ} \mathrm{C}\right)$ & 25 & 35 & 45 \\
\hline \multirow{5}{*}{ Langmuir } & $\mathrm{q}_{\max }\left(\mathrm{mg} \mathrm{g}^{-1}\right)$ & 88.03 & 102.04 & 113.96 \\
\cline { 2 - 5 } & $\mathrm{K}_{\mathrm{L}}\left(\mathrm{L} \mathrm{mg}^{-1}\right)$ & 2,777 & 1.355 & 0.735 \\
\cline { 2 - 5 } & $\mathrm{R}^{2}$ & 1.000 & 0.999 & 0.999 \\
\hline \multirow{5}{*}{ Freundlich } & $\mathrm{K}_{\mathrm{F}}\left(\mathrm{mg} \mathrm{g}^{-1}\right)\left(\mathrm{L} \mathrm{mg}^{-1}\right)^{1 / \mathrm{n}}$ & 66.32 & 71.59 & 75.56 \\
\cline { 2 - 5 } & $1 / \mathrm{n}$ & 0.0674 & 0.0832 & 0.0092 \\
\cline { 2 - 5 } & $\mathrm{R}^{2}$ & 0.947 & 0.984 & 0.998 \\
\hline \multirow{5}{*}{ Temkin } & $\mathrm{A}_{\mathrm{T}}\left(\mathrm{L} \mathrm{g}^{-1}\right)$ & $76.91 \times 10^{4}$ & $6.85 \times 10^{4}$ & $2.55 \times 10^{4}$ \\
\cline { 2 - 5 } & $\mathrm{B}_{\mathrm{T}}\left(\mathrm{J} \mathrm{mol}^{-1}\right)$ & 500.67 & 388.68 & 342.98 \\
\cline { 2 - 5 } & $\mathrm{R}^{2}$ & 0.952 & 0.989 & 0.997 \\
\hline \multirow{5}{*}{ Dubinin-Radushkevich } & $\mathrm{q}_{\mathrm{d}}\left(\mathrm{mg} \mathrm{g}^{-1}\right)$ & 87.13 & 98.72 & 106.62 \\
\cline { 2 - 5 } & $\beta\left(\mathrm{mol}^{2} \mathrm{~kJ}^{-2}\right)$ & 0.0312 & 0.0192 & 0.0145 \\
\cline { 2 - 5 } & $\mathrm{E}\left(\mathrm{kJ} \mathrm{mol}^{-1}\right)$ & 4.0009 & 5.0867 & 5.8593 \\
\cline { 2 - 5 } & $\mathrm{R}^{2}$ & 0.997 & 0.966 & 0.934 \\
\hline
\end{tabular}

Table 3. Thermodynamic parameters for AB80 adsorption onto NAC at various temperatures

\begin{tabular}{|c|c|c|c|}
\hline Temperature $\left({ }^{\circ} \mathrm{C}\right)$ & $\Delta \mathrm{G}^{\mathrm{o}}\left(\mathrm{kJ} \mathrm{mol}^{-1}\right)$ & $\Delta \mathrm{H}^{\mathrm{o}}\left(\mathrm{kJ} \mathrm{mol}^{-1}\right)$ & $\Delta \mathrm{S}^{\mathbf{o}}\left(\mathrm{kJ}(\mathrm{mol} \mathrm{K})^{-1}\right)$ \\
\hline 25 & -11.768 & 46.018 & 0.227 \\
\hline 35 & -14.010 & & \\
\hline 45 & -15.637 & & \\
\hline
\end{tabular}

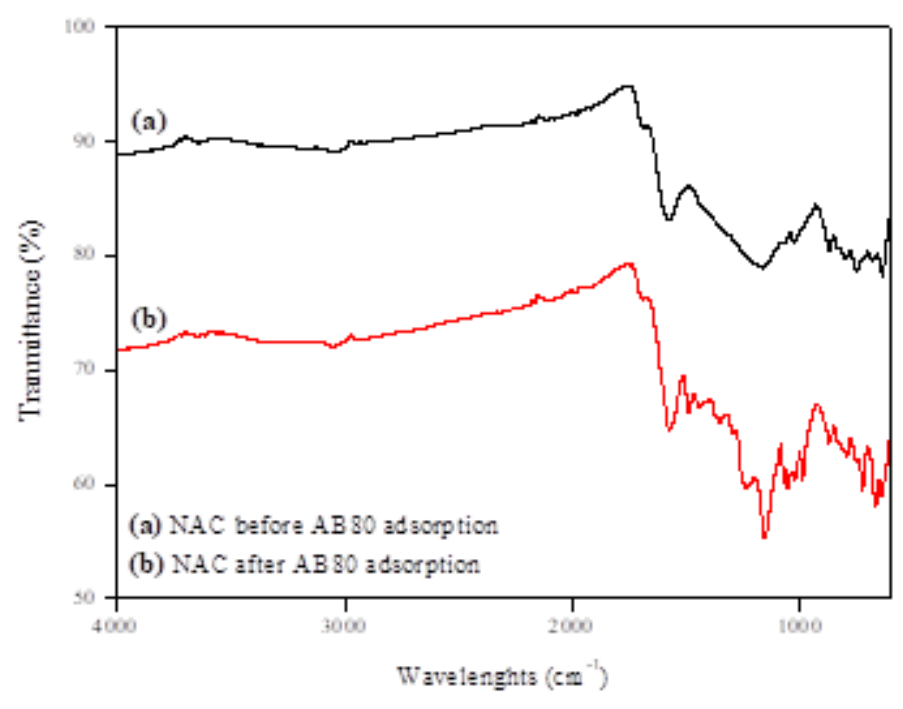

Figure 5. FTIR spectra of NAC (a) before and (b) after AB80 adsorption 


\section{CONCLUSION}

Acid blue 80 adsorption experiments by using the activated carbon prepared from Nerium oleander fruits were carried out. To remove AB80 with the percentage of higher than $99.00 \%$ from the aqueous solution, $0.68,1.33,1.95$, and $2.60 \mathrm{mg} \mathrm{mL}^{-1} \mathrm{NAC}$ was found to be sufficient for the removals of 40 , 80,120 , and $160 \mathrm{mg} \mathrm{L}^{-1} \mathrm{AB} 80$ at $25{ }^{\circ} \mathrm{C}$, respectively. Also, increasing adsorption temperature led to increase in $\mathrm{AB} 80$ adsorption capacity by NAC. AB80 adsorption capacity increased as adsorption $\mathrm{pH}$ decreased. Langmuir isotherm model and pseudo second order model were determined to be best fitting models for AB80 adsorption on NAC, and its maximum adsorption capacities were calculated to be $88.03,102.04$, and $113.96 \mathrm{mg} \mathrm{g}^{-1}$ at 25,35 , and $45{ }^{\circ} \mathrm{C}$, respectively. While the rate of $\mathrm{AB} 80$ adsorption on NAC was found to be fast during the first 60 minutes, AB80 adsorption velocity decreased with passing contact time. Furthermore, AB80 adsorption on NAC was determined to be spontaneous, feasible, and endothermic.

\section{ACKNOWLEDGMENT}

The author special thanks to Kırklareli University Central Research Laboratory (Advanced Technologies Application and Research Center) for using its experimental and measurement instruments.

\section{CONFLICT OF INTEREST}

The Author reports no conflict of interest relevant to this article.

\section{RESEARCH AND PUBLICATION ETHICS STATEMENT}

The author declares that this study complies with research and publication ethics.

\section{REFERENCES}

Abechi, S.E., Gimba, C.E., Uzairu, A., Dallatu, Y.A., 2013. Preparation and characterization of activated carbon from palm kernel shell by chemical activation. Research Journal of Chemical

Sciences, 3(7):54-61.

Aboua, K.N., Yobouet, Y.A., Yao, K.B., Gone, D.L., Trokourey, A., 2015. Investigation of dye adsorption onto activated carbon from the shells of Macoré fruit. Journal of Environmental Management, 156:10-14.

Ai, L., Zhang, C., Liao, F., Wang, Y., Li, M., Meng, L., Jiang, J., 2011. Removal of methylene blue from aqueous solution with magnetite loaded multi-wall carbon nanotube: kinetic, isotherm and mechanism analysis. Journal of Hazardous Materials, 198:282290.

Ali H., 2010. Biodegradation of synthetic dyes - a review. Water, Air, \& Soil Pollution, 213(1):251-273.

Ambati, R., Gogate, P.R., 2017. Photocatalytic degradation of Acid Blue 80 using iron doped TiO 2 catalyst: Understanding the effect of operating parameters and combinations for synergism. Journal of Water Process Engineering, 20:217-225.

Baccar, R., Bouzid, J., Feki, M., Montiel, A., 2009. Preparation of activated carbon from Tunisian olivewaste cakes and its application for adsorption of heavy metal ions. Journal of Hazardous Materials, 162(2-3):1522-1529.

Bakıcı Tanaydın, Z., Tanaydın, M., İnce, M., Demirkıran, N., 2020. Bakır ve Kadmiyumun Perlit ile Adsorpsiyonu ve Adsorpsiyon Özelliklerinin Karşılaştırılması. International Journal of Pure and Applied Sciences, 6(2):208-218.

Balarak, D., Dashtizadeh, M., Abasizade, H., Baniasadi, M., 2018. Isotherm and Kinetic Evaluation of Acid Blue 80 Dye Adsorption on Surfactant-modified Bentonite. Journal of Human, Environment and Health Promotion, 4(2):75-80.

Baysal, M., Bilge, K., Yılmaz, B., Papila, M., Yürüm, Y., 2018. Preparation of high surface area activated carbon from waste-biomass of sunflower piths: Kinetics and equilibrium studies on the dye removal. Journal of Environmental Chemical Engineering, 6(2):1702-1713.

Beltrame, K.K., Cazetta, A.L., de Souza, P.S., Spessato, L., Silva, T.L., Almeida, V.C., 2018. Adsorption of caffeine on mesoporous activated carbon fibers prepared from pineapple plant leaves. Ecotoxicology and Environmental Safety, 147:64-71.

Bhattacharyya, S., Das, P., Datta, S., 2019. Removal of Ranitidine from Pharmaceutical Waste Water Using 
Activated Carbon (AC) Prepared from Waste Lemon Peel. In Waste Water Recycling and Management (pp. 123-141). Springer, Singapore.

Dávila-Jiménez, M.M., Elizalde-González, M.P., Hernández-Montoya, V., 2009. Performance of mango seed adsorbents in the adsorption of anthraquinone and azo acid dyes in single and binary aqueous solutions. Bioresource Technology, 100(24):6199-6206.

Demiral, H., Güngör, C., 2016. Adsorption of copper (II) from aqueous solutions on activated carbon prepared from grape bagasse. Journal of Cleaner Production, 124:103-113.

Dubinin, M.M., Radushkevich, L.V., 1947. The equation of the characteristic curve of activated charcoal. Proc Academy of Sciences of the USSR Physical Chemistry Section, 55:331-337.

Freundlich, H.M.F., 1906. Über die adsorption in lösungen. Zeitschrift für Physikalische Chemie, 57:385-470.

Gomri, F., Boutahala, M., Zaghouane-Boudiaf, H., Korili, S. A., Gil, A., 2016. Removal of acid blue 80 from aqueous solutions by adsorption on chemical modified bentonites. Desalination and Water Treatment, 57(54):26240-26249.

Hadi, M., Samarghandi, M.R., McKay, G., 2010. Equilibrium two-parameter isotherms of acid dyes sorption by activated carbons: study of residual errors. Chemical Engineering Journal, 160(2):408416.

Hameed, B.H., Ahmad, A.A., 2009. Batch adsorption of methylene blue from aqueous solution by garlic peel, an agricultural waste biomass. Journal of Hazardous Materials, 164(2-3): 870-875.

Hassaan, M.A., El Nemr, A., 2017. Health and Environmental Impacts of Dyes: Mini Review. American Journal of Environmental Science and Engineering, 1(3):64-67.

Ho, Y.S., McKay, G., 1999. Pseudo-second order model for sorption processes. Process Biochemistry, 34:451-465.

Ince, M., Kaplan İnce, O., 2017. An Overview of Adsorption Technique for Heavy Metal Removal from Water/Wastewater: A Critical Review. International Journal of Pure and Applied Sciences, 3(2):10-19.

Karim, M.M., Das, A.K., Lee, S.H., 2006. Treatment of colored effluent of the textile industry in Bangladesh using zinc chloride treated indigenous activated carbons. Analytica chimica acta, 576(1):37-42.

Koçer, O., Acemioğlu, B., 2016. Adsorption of Basic green 4 from aqueous solution by olive pomace and commercial activated carbon: process design, isotherm, kinetic and thermodynamic studies. Desalination and Water Treatment, 57(35):16653-16669.

Köseoğlu, E., Akmil-Başar, C., 2015. Preparation, structural evaluation and adsorptive properties of activated carbon from agricultural waste biomass. Advanced Powder Technology, 26(3):811818.

Kyzas, G.Z., Deliyanni, E.A., Matis, K.A., 2016. Activated carbons produced by pyrolysis of waste potato peels: cobalt ions removal by adsorption. Colloids and Surfaces A: Physicochemical and Engineering Aspects, 490:7483.

Lagergren, S., 1898. Zur theorie der sogenannten adsorption gelöster stoffe. Kungliga Svenska Vetenskapsakademiens Handlingar, 24:1-39.

Lakherwal D., 2014. Adsorption of heavy metals: a review. International Journal of Environmental Research and Development, 4(1):41-48.

Langmuir, I., 1916. The constitution and fundamental properties of solids and liquids. Journal of American Chemical Society, 38:2221-2295.

Liu, Y., Luo, X., Zhang, Z., Zhou, P., Yang, Z., 2015. Modeling and thermodynamics of methylene blue and acid blue 80 adsorption onto potato residue based activated carbon. Chemical Research in Chinese Universities, 31(4):627-632.

Ma, Z., Sun, Q., Ye, J., Yao, Q., Zhao, C., 2016. Study on the thermal degradation behaviors and kinetics of alkali lignin for production of phenolic-rich bio-oil using TGA-FTIR and Py-GC/MS. Journal of Analytical and Applied Pyrolysis, 117:116-124.

Martins, A.C., Pezoti, O., Cazetta, A.L., Bedin, K.C., Yamazaki, D.A., Bandoch, G.F., Asefa, T., Visentainer, J.V., Almeida, V.C., 2015. Removal of tetracycline by $\mathrm{NaOH}$-activated carbon produced from macadamia nut shells: kinetic and equilibrium studies. Chemical Engineering Journal, 260:291299.

Milonjić, S.K., Ruvarac, A.L., Šušić, M.V., 1975. The heat of immersion of natural magnetite in aqueous solutions. ThermochimicaActa, 11:261-266. 
Mohan, P.K., Sreelakshmi, G., Muraleedharan, C.V., Joseph, R., 2012. Water soluble complexes of curcumin with cyclodextrins: Characterization by FT-Raman spectroscopy. Vibrational Spectroscopy, 62:77-84.

Nasrullah, A., Saad, B., Bhat, A.H., Khan, A.S., Danish, M., Isa, M.H., Naeem, A., 2019. Mangosteen peel waste as a sustainable precursor for high surface area mesoporous activated carbon: Characterization and application for methylene blue removal. Journal of Cleaner Production, 211:1190-1200.

Nogales-Bueno, J., Baca-Bocanegra, B., Rooney, A., Hernández-Hierro, J.M., Byrne, H.J., Heredia, F.J., 2017. Study of phenolic extractability in grape seeds by means of ATR-FTIR and Raman spectroscopy. Food Chemistry, 232:602-609.

Pandiarajan, A., Kamaraj, R., Vasudevan, S., Vasudevan, S., 2018. OPAC (orange peel activated carbon) derived from waste orange peel for the adsorption of chlorophenoxyacetic acid herbicides from water: adsorption isotherm, kinetic modelling and thermodynamic studies. Bioresource Technology, 261:329-341.

Puentes-Cárdenas, I.J., Chávez-Camarillo, G.M., FloresOrtiz, C.M., Cristiani-Urbina, M.D.C., NetzahuatlMuñoz, A.R., Salcedo-Reyes, J.C., PedrozaRodríguez, A.M., Cristiani-Urbina, E., 2016. Adsorptive removal of acid blue 80 dye from aqueous solutions by $\mathrm{Cu}-\mathrm{TiO} 2$. Journal of Nanomaterials, 2016:1-15.

Qiu, W.Z., Yang, H.C., Wan, L.S., Xu, Z.K., 2015. Codeposition of catechol/polyethyleneimine on porous membranes for efficient decolorization of dye water. Journal of Materials Chemistry A, 3(27):14438-14444.

Rashid, R., Shafiq, I., Akhter, P., Iqbal, M.J., Hussain, M., 2021. A state-of-the-art review on wastewater treatment techniques: the effectiveness of adsorption method. Environmental Science and Pollution Research, 1-17. https://doi.org/10.1007/s11356-02112395-x

Rashidi, N.A., Yusup, S.A., 2017. Review on recent technological advancement in the activated carbon production from oil palm wastes. Chemical Engineering Journal, 314:277-290.

Sabarinathan, C., Karuppasamy, P., Vijayakumar, C.T., Arumuganathan, T., 2019. Development of methylene blue removal methodology by adsorption using molecular polyoxometalate: Kinetics,
Thermodynamics and Mechanistic Study. Microchemical Journal, 146:315-326.

Shankar, Y.S., Ankur, K., Bhushan, P., Mohan, D., 2019. Utilization of Water Treatment Plant (WTP) Sludge for Pretreatment of Dye Wastewater Using Coagulation. Advances in Waste Management, 107121. https://doi.org/10.1007/978-981-13-0215-2_8

Shi, B., Li, G., Wang, D., Feng, C., Tang, H., 2007. Removal of direct dyes by coagulation: The performance of preformed polymeric aluminum species. Journal of Hazardous Materials, 143(12):567-574.

Silva, T.L., Cazetta, A.L., Souza, P.S., Zhang, T., Asefa, T., Almeida, V.C., 2018. Mesoporous activated carbon fibers synthesized from denim fabric waste: efficient adsorbents for removal of textile dye from aqueous solutions. Journal of Cleaner Production, 171, 482-490.

Tee, P.C., Wong, Y.J., Sherry, J.P., Bols, N.C., 2011. Effect of acid blue 80, an anthracenedione dye, on rainbow trout liver, gill and gut cells in vitro. Ecotoxicology and Environmental Safety, 74(7):1874-1878.

Temkin, M.I., Pyzhev, V., 1940. Kinetic of ammonia synthesis on promoted iron catalyst. Acta PhysChim USSR, 12:327-356.

Tong, D.S., Wu, C.W., Adebajo, M.O., Jin, G.C., Yu, W. H., Ji, S.F., Zhou, C.H., 2018. Adsorption of methylene blue from aqueous solution onto porous cellulose-derived carbon/montmorillonite nanocomposites. Applied Clay Science, 161, 256264.

Türgay, O., Ersöz, G., Atalay, S., Forss, J., Welander, U., 2011. The treatment of azo dyes found in textile industry wastewater by anaerobic biological method and chemical oxidation. Separation and Purification Technology, 79(1):26-33.

Üner, O., Geçgel, Ü., Avcu, T., 2021. Comparisons of activated carbons produced from sycamore balls, ripe black locust seed pods, and Nerium oleander fruits and also their $\mathrm{H}_{2}$ storage studies. Carbon Letters. 31:75-92.

Üner, O., Geçgel, Ü., Bayrak, Y., 2016. Adsorption of methylene blue by an efficient activated carbon prepared from Citrullus lanatus rind: kinetic, isotherm, thermodynamic, and mechanism analysis. Water, Air, \& Soil Pollution, 227(7), 1-15.

Üner, O., Geçgel, Ü., Bayrak, Y., 2019. Preparation and characterization of mesoporous activated carbons 
DOI: 10.29132/ijpas.908703

from waste watermelon rind by using the chemical activation method with zinc chloride. Arabian Journal of Chemistry, 12(8):3621-3627.

Üner, O., Geçgel, Ü., Kolancilar, H., Bayrak, Y., 2017. Adsorptive removal of rhodamine $b$ with activated carbon obtained from okra wastes. Chemical Engineering Communications, 204(7):772-783.

Wong, S., Ngadi, N., Inuwa, I.M., Hassan, O., 2018. Recent advances in applications of activated carbon from biowaste for wastewater treatment: a short review. Journal of Cleaner Production, 175:361375.

Yahya, M.A., Al-Qodah, Z., Ngah, C.Z., 2015. Agricultural bio-waste materials as potential sustainable precursors used for activated carbon production: A review. Renewable and Sustainable Energy Reviews, 46:218-235. 